\title{
教育講演
}

\section{8. がん緩和医療}

\section{江口 研二}

Key words : がん対策基本法, 緩和医療, がん緩和ケア, 地域連携, 緩和医療専門医

\section{はじめに}

2006 年に成立した「がん対策基本法」は，全 国に質の高いがん医療を普及させ，患者・家族 に安心できる療養生活を実現することを目的と した画期的な法律である ${ }^{1)}$. 2008 年にはこの法律 をもとに，各都道府県のがん対策推進計画が策 定され，各地域でさまざまな取り組みが現在行 われており, 厚労省は, 推進計画進渉状況とそ の実績に関して中間評価に入っている．質の高 いがん緩和医療の普及とそれに必要な人材の育 成は, がん対策推進計画の中で主要目標のひと つになっている(表 1 )。言葉の定義として,「緩 和ケア」とは, 実地の緩和的な対処行為全体を 意味するもので,「緩和医療」あるいは「緩和医 療学」という言葉は, 苦痛となる症状の緩和に 関する医療上の診療領域およびその臨床的・基 礎的な学問分野をさす.

\section{1. 本邦におけるがん緩和医療の発展}

1972 年に大阪市にある淀川キリスト教病院で 終末期患者の看取りのケア体制について内容の

えぐち けんじ：帝京大学内科学講座（帝京がんセン 夕一・腫瘍内科)

本講演は, 平成 22 年 4 月 11 日（日）東京都・東京国 際フォーラムにて行われた.
表 1 がん対策基本法 $\mathrm{H} 18$ 年 6 月 がん対策推進計画 閣議決定 $\mathrm{H} 19$ 年 6 月(抜粋)

がんによる死亡率を20\%へらす

がん患者・家族の苦痛の軽減

患者の意向を尊重した医療体制整備

放射線治療・薬物療法（抗癌剤）の專門家の育成 緩和医療の充実

がん対策基本法 16 条 療養生活の質の向上と維持

国・地方公共団体は，がん患者の状況に応じて 疼痛等の緩和を目的亡する医療が早期から行われる, 居宅において医療を提供する連携協力体制を確保する。 医療従事者への研修，など 必要な施策を講ずること

(抜粋)

統一化が行われ，1981 年には，がん終末期医療 を担う緩和ケア専用病床としては, 日本で初め て浜松市の聖隷三方が原病院に, ホスピス病棟 が設置された。その後も本邦では，がん緩和医 療はホスピスを中心に発展してきた. 2010 年に, 厚生労働省認可のホスピス・緩和ケア病棟は, 全国約 360 力所, 病床数にして 4,060 床になって いる。このような背景をもとに, 医療関係者や 市民の間では，がん緩和医療＝終末期医療とい う認識が根付いていた（表 2).

しかし現在のがん緩和医療は，がん治療を中 止して緩和医療に入るという図式ではなく，が ん患者の日常生活上支障となる身体的・精神的 な苦痛を早期から軽減し患者・家族の快適な療 養を実現することを目指している（WHO 2002 年 $)^{2)}$. 従って, 緩和医療は終末期医療のみなら 
表 2. わが国のがん緩和ケアの歩み

\begin{tabular}{|c|c|}
\hline 淀川キリスト教病院＼cjkstart看取りケア体制の統一 (OCDP) & 1972 \\
\hline 日本死の臨床研究会 設立 & 1977 \\
\hline わが国最初のホスピス＼cjkstart聖隷三方原病院ホスピス設立 & 1981 \\
\hline WHO 編集の小冊子 『がんの痛みからの解放』出版 & 1987 \\
\hline 厚生省「末期医療に関するケアのあり方検討会」 報告書 & 1989 \\
\hline 診療報酬「緩和ケア病棟入院料」 設置 & 1990 \\
\hline 全国ホスピス・緩和ケア病棟連絡協議会 設立 & 1991 \\
\hline 日本緩和医療学会 設立 & 1996 \\
\hline ホスピスケア（緩和ケア）認定看護師制度 発足 & 1998 \\
\hline 病院緩和ケアチーム＼cjkstart診療報酬「緩和ケア診療加算」 & 2002 \\
\hline
\end{tabular}

ず，がん診療の一連の経過を通じて，同時並行 的に，早期から行われるものという認識に発展 した．実際には全国各地で通院しながらがん治 療を受けている患者が増加しており，これらの 患者は日常生活の中で疼痛など生活上の制約と なるさまざまな身体的・精神的症状をがんの治 療と同時に通院しながら治療している.

がん緩和医療の対象となる症状としては, 疼 痛対策, 消化器症状, 呼吸困難, 栄養, うつ. せん妄などがあり, がんに伴う身体症状・精神 症状を多職種の専門家からなるチーム医療とし て対処する。医学的には治癒したと思われる術 後早期癌であっても, 治療後に生じうる身体的 （機能障害や後遺症）・精神的（再発に対する不 安や社会的な差別など）な苦痛に悩む患者は多 い. 外来通院治療の普及と共に, 抗癌剂・放射 線・手術療法などがん治療にともなう副作用対 策としての支持療法も広義にがん緩和医療に含 まれる。

身体的・心理的苦痛だけでなく, 希望する療 養形態, 医療スタッフとの関係, 生き甲斐 (spirituality)の維持, 家族・友人などへの配慮など, さまざまな要素が患者の療養生活に影響を与え る．緩和医療として非常に多いがん性疼痛につ いても, 患者自身の症状による苦痛の程度・感 じ方に比べ，その症状の内容・程度に関して， 医療者の評価が非常に甘いという調査結果は数 多く報告されている.

\section{2. がん緩和ケアチームおよび地域緩和医 療体制}

2004 年入院患者に対するがん緩和ケアチーム の保険診療加算が開始された. 認定された緩和 ケアチームは, 専属の緩和医療医, 精神科医, 認定資格を持つ看護師・薬剤師の最低 4 名で多 職種専門家によるチームを作り，医療機関内の がん関連診療科からの依頼により, 専門的な緩 和医療の診療をアドバイスする，全国がん診療 連携拠点病院の現状調査（2009 年公表）では, 設置要件に合致する緩和ケアチームは，90/377 施設 $(24 \%)$ しか充足されていない3). 医療機関 全体としての緩和医療取り組み姿勢, 院内各診 療科による緩和医療に対する認識普及, スタッ フ養成体制整備など, 緩和ケアチーム活動のバ リアーを解決して, 患者・家族が安心できる療 養支援を展開する必要がある。実際のユーザー となる患者・家族そして，主治医などの医療ス タッフが，緩和ケアチームの利便性を実感とし て感じられることが活用される原動力となる. 緩和ケアチームは専門的緩和ケアを提供する(表 $3)$.

がん療養のあり方の中で, 患者が自ら希望す る療養場所の選択肢を増やすことは患者の生活 の質を重視する点で大切である.この実現には, 地域におけるがん医療連携を構築することが必 
表 3. 基本的な緩和ケアと専門的な緩和ヶア
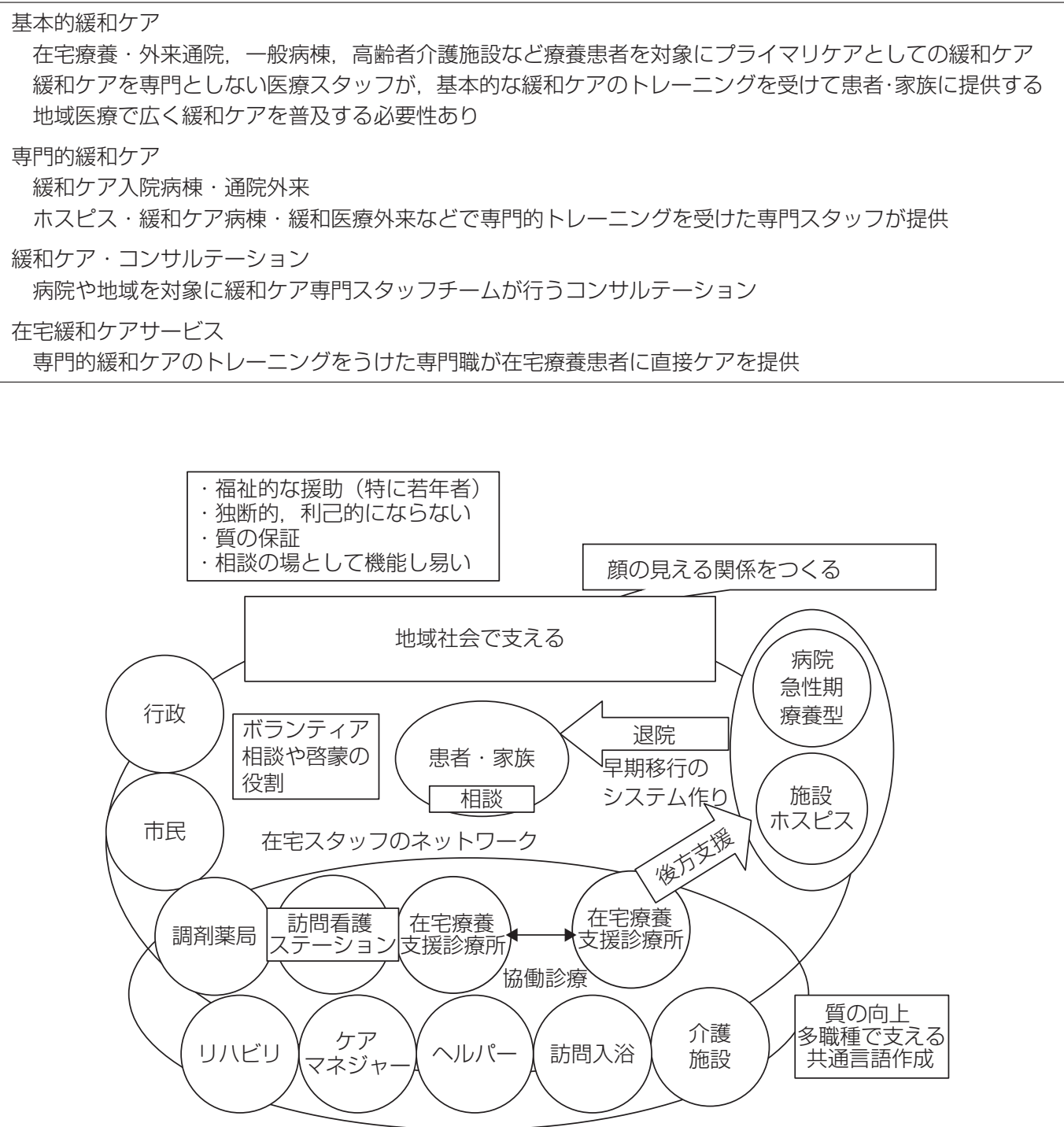

図．地域連携における役割分担と協調

要となる. 現在, 地域で在宅療養をふくめた緩 和医療が機能的に運営されているグループをモ デル化すると次のようになる。すなわち，早期 からの在宅がん緩和医療をめざす地域連携の体 制として，1）がん診療の中核病院主導型，2） 地域医師会の連携主導型, 3）在宅緩和医療専門 医師主導型の 3 つのモデルに大別される，1) 3）のいずれの場合にも, がん緩和医療に精通し,
且つ多職種スタッフ間のコンダクターとしての 資質を備えた，連携グループのコアとなる医師 と, 緩和医療に経験豊富で地域の医療事情に精 通する看護師とのトリアージ的活動が重要であ る. 医療・介護機関，さらに当該行政担当者， 調剂薬局などの定期的な連絡会議等で，組織と して「お互いの顔の見える関係」を構築し各々 の施設が役割分担を行う必要がある。がん治療 
と療養生活の集中と分散をうまく調和させるこ とがポイントである(図)。組織制度, 医療者,

患者家族, 医療機関組織などの要因が大きく活 動に影響することが明らかであり，一律の地域 がん緩和医療体制モデルでなく，各地域の特性 に会わせた柔軟な工夫が必要である. 外来化学 療法などの通院がん患者も大幅に増え, 患者・ 家族の要望をどのように取り込むか, 緩和医療 外来をどのように運営するか, また従来型の緩 和医療病棟を, 在宅療養の緊急時後方病床や介 護家族レスパイト(介護者を一時的に休ませる) のための一時入院病床などに利用するといった 対応が計られつつある。地域連携による緩和医 療体制構築のために，(1) 医療・介護機関の間 で共有する標準的な臨床情報の媒体，（2）対象 患者のスクリーニングシステムの作成，（3）緩 和ケア支援センターに拈ける在宅・病院・医療・ 介護などの地元情報の提供とリクルート体制構 築，（4）患者・家族への情報提供とトリアージ 機能（適切な振り分け）,（5）地域緩和医療を支 える医療関係者および地域の一般市民を対象と した教育・啓発プログラム作成などが, 緊急課 題となっている ${ }^{4)}$.

がん緩和医療に関する体系的な症状別ガイド ラインとしては日本緩和医療学会 (http ://www. jspm.ne.jp) から「がん疼痛」「鎮静」「終末期補液」 「補完代替療法」などが公表ないし出版されてい る。がん緩和医療の教育研修については，同じ く日本緩和医療学会が緩和医療統一カリキュラ ムに準拠した一般医療者向けの定期教育セミナー (年 2 回開催) と専門的な緩和医療指導者講習会 (PEACE Project) とを教育研修事業として実施 している5 .さらに, 日本緩和医療学会では, 2009 年度に緩和医療専門医の資格認定を発足させ, 2010 年 3 月には全国で 12 名の専門医が初めて誕 生した。がん対策推進計画の中で，拡充目標と される放射線治療の専門医（日本放射線腫瘍学 会), がん薬物療法の専門医 (日本臨床腫瘍学会) が各々数百名に達しつつあり, また，がん医療

\section{表 4. 日本緩和医療学会 緩和医療専門}

申請資格

日本国医師免許証

5 年以上の緩和医療臨床経験又は「がんプロ フェッショナル養成プラン緩和医療専門医コース」 修了者

本学会認定の認定研修施設で 2 年以上の緩和医療 臨床研修修了者 (申請年よりさかのぼつて 5 年 以内)

自ら緩和医療を担当した20 例の症例報告（書式 指定）うち 10 例以上は認定研修施設の症例 緩和医療に関する教育歴

緩和医療に関する筆頭原著論文または症例報告 かつ学会発表の業績

本学会認定の講習会受講歴

2 年以上継続した学会会員 (申請時)

資格審査

教育歴・業績・臨床歴の審査

症例報告の採点審査

筆記試験・ 口頭試問の採点審査

専門医審査部会・理事会承認

専門医資格は 5 年毎に更新

（文献 5 より）

関連領域の専門看護師約 200 名, 認定看護師約 1,700 名 (5 領域) がん認定薬剤師（日本緩和医 療薬学会）約 160 名に比べて, 緩和医療専門医 はまだ制度的に誕生期にある ${ }^{6}$. 今後, 全国のが ん診療連携拠点病院などに複数の専門医配置を 考慮すると, 3 年間で約 1,000 名, 数年間でその 2 倍ぐらいを目標にする必要がある（表 4). 現 状では，指導者講習などを修了して現役で活躍 している専門家を核として, 地域内での緩和医 療教育体制を作り, 在宅医療関係者, 関連スタッ フの技量の向上や，地域社会での一般市民への 啓発活動の仕組みを活用する必要がある。緩和 医療の専門医を人材として育成するためには, 現在 3 大学にしかない正規の緩和医療学講座を 全国の医科大学に設置し，医学教育・医療教育 を通して一貫した緩和医療専門家の人材育成を 行うことが必須である.

がん疼痛対策を始め, この 10 年間, 国内でが ん緩和医療に使用できる薬剤の種類や剂型が急 速に増え，様々なリスクを抱えるがん患者に対 して, 緩和治療における治療法選択の幅が広がっ た。しかし, 適切な治療が, 全国どこの医療機 
関，どの診療科でも受けられるかというと，実 情はきわめて不十分な状況である。緩和医療に 関する適切な卒前卒後教育体制および卒後の臨 床研修教育制度の中で，がん緩和医療に関する 適切な教育を実施できる体制の整備が必要であ る. Cancer survivors（がん治療を経験して生活 している人たち）が，年間 150 万人を超え，さ らに国民の 2 人に 1 人ががんを経験するといわ れる時代を迎え, がん緩和医療の重要性は一層 大きくなると考えられる.

\section{文献}

1）がん対策基本法 http://law.e-gov.go.jp/announce/H18 HO098.html がん対策推進計画 http://www.mhlw.g o.jp/shingi/2007/s0615-1.html

2) WHO : Pain relief and palliative care. National Cancer Control programmes. Policies and managerial guidelines, $2^{\text {nd }}$ edn, World Health Organization, Geneva, 2002.

3）がん診療連携拠点病院における緩和ケアの横断的調查 （国立がんセンターがん研究情報センター）http://ganj oho.jp/public/2010/20100302.html

4）厚労省戦略研究The OPTIM study http://gankanwa.jp

5）日本緩和医療学会the Japanese Society for Palliative Medicine http://www.jspm.ne.jp

6）がんプロフェッショナル養成コース 文部科学省 htt p://www.mext.go.jp/a_menu/koutou/kaikaku/gan.ht $\mathrm{m}$ 